\title{
A anarquia social: resistência, insurgência e revolução social na teoria de Bakunin

\author{
The social anarchy: resistance, insurgency
} and social revolution in the theory of Bakunin
}

\author{
Selmo Nascimento da Silva \\ Doutorando em História pela Universidade Federal Fluminense \\ Professor do Departamento de Sociologia do Colégio Pedro II \\ selmons2000@gmail.com
}

\begin{abstract}
Resumo: O presente artigo tem o objetivo debater os fundamentos da teoria anarquista de Mikhail Bakunin, analisando o contexto de seu desenvolvimento, ou seja, o contexto da luta de classes na Europa no período do ciclo revolucionário que tem seu início no ano de 1848 , e que assume o caráter organizativo do internacionalismo dos trabalhadores, culminando no novo ciclo insurrecional iniciado pela Comuna de Paris (1871). Essa contextualização visa superar as definições arbitrárias e a-históricas sobre a noção de anarquismo e da própria obra de Bakunin e, ao mesmo tempo, recuperar sua historicidade. Assim, sua teoria, sua perspectiva materialista, sua dialética, sua concepção revolucionária de anarquia social tornam-se de fato inteligíveis. Os conceitos da teoria bakuninista aqui destacados são de anarquia social e de trabalho insurgente.
\end{abstract}

Palavras-chaves: Bakunin. Anarquismo. Dialética serial. Insurgência. Revolução social.

\begin{abstract}
This article aims to discuss the fundamentals of anarchist theory of Mikhail Bakunin, analyzing the context of development, ie the class struggle context in Europe in the revolutionary cycle period which begins in the year 1848, and takes the organizational character of workers' internationalism, culminating in the new insurrectionary cycle initiated by the Paris Commune (1871). This contextualization aims to overcome the arbitrary and ahistorical definitions of the notion of anarchism and the very work of Bakunin and at the same time, recover its historicity. So his theory, its materialism, its dialectic, its revolutionary conception of social anarchy become intelligible fact. The concepts highlighted here Bakuninist theory are social anarchy and insurgent work.
\end{abstract}

Keywords: Bakunin. Anarchism. Serial dialectic. Insurgency. Social revolution.

Originais recebidos em: 01/07/2015

Aceito para publicação: 17/09/2015

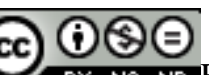

Comercial-Vedada a criação de obras derivadas 3.0 Unported License. 


\section{Introdução}

O ano de 2014 foi o ano do bicentenário do nascimento do anarquista russo Mikhail Bakunin (1814-2014), por isso, em diversos países ocorreram iniciativas para o debate de suas ideias revolucionárias ${ }^{1}$. No Brasil um acontecimento controvertido rendeu certa repercussão nas redes sociais. Segundo a professora de filosofia, Camila Jourdan, processada sob a acusação de participar de atos violentos na cidade do Rio de Janeiro, a polícia fluminense investigou Bakunin por suposta participação nos atos de rua, passando, assim, a constar nos autos do processo contra os perseguidos políticos. ${ }^{2}$ Diante dessa situação inusitada, foi criada um perfil nas redes sociais sob o título de BakuninSuspeito ${ }^{3}$ que no início de 2015 já contava com certa de 26 mil seguidores, que se especializou em fazer anedotas com a investigação de um revolucionário morto desde 1876.

Apesar do caráter inusitado e, até mesmo, anedótico desse fato, ele faz parte da onda de criminalização, repressão e punição das ideias e práticas subversivas, que ocorreu após o levante popular de junho de 2013. Essa onda se associa aos mecanismos contínuos de repressão e controle social sobre as classes perigosas, que caracterizam a dominação de classe na sociedade brasileira ${ }^{4}$.

A recente criminalização da ideologia anarquista tem como marco a seguinte manchete da Revista Veja: “Anarquistas: os organizadores do caos nas passeatas: entre os vândalos que macularam os protestos há desde militantes de esquerda até pitboys sem causa, mas são os anarquistas que incitam o quebra-quebra" (VEJA, 23/06/2013). A reportagem assinada pelo jornalista Leonardo Coutinho reproduz um conjunto de estereótipos sobre as a ideologia anarquista e sobre as próprias manifestações e práticas insubmissas e insurgentes das classes populares, condenando especialmente o que denomina de tática "black bloc". Mas o que começou com uma reportagem preconceituosa culminou num processo movido pelo Ministério Público do Rio de Janeiro contra 23 militantes políticos, cujo caráter de patrulhamento e perseguição

$1 \mathrm{Na}$ página https://bakunin2014.wordpress.com encontram-se algumas das iniciativas visando o debate sobre as ideias de Bakunin em função do seu bicentenário.

2 Ver a entrevista da professora Camila Joudan na página: http://www1.folha.uol.com.br/poder/2014/07/1492074-acusada-de-articular-atos-violentos-professoradiz-que-inquerito-e-ficcao.shtml.

3 Conferir https://www.facebook.com/BakuninSuspeito.

4 Durante o levante popular de junho de 2013 a maior repressão policial no Rio de Janeiro ocorreu na Favela da Maré, onde na passagem do dia 24 para 25, o Batalhão de Operações Especiais (BOPE) realizou uma ação para reprimir um protesto na Avenida Brasil. Na operação os policiais do BOPE executaram 11 moradores da Favela da Maré. Esse massacre durante o levante popular, que ocorreu durante a Copa da Confederações.

Em Debat: Rev. Dig., ISSNe 1980-3532, Florianópolis, n. 11, p. 26-46, jan-jun, 2014. 
ideológica é evidente, conforme explicita o seguinte trecho do inquérito policial que originou o processo:

A OATL [Organização Anarquista Terra e Liberdade] é uma organização (...) com o objetivo de disseminar a filosofia anarquista através de ações diretas com depredações a patrimônios públicos e privados, enfrentamento a policiais, pichações e resistência em ocupações, utilizando seus integrantes (...) para fazer rondas de carros nos protestos esperando o momento certo para surpreender a polícia jogando bombas e coquetéis "molotov", bem como para carregar explosivos no interior das mochilas para serem distribuídos por isso mantém forte aproximação com jovens adeptos da tática "BLACK BLOC”. (BRASIL, 2013)

As referências ao anarquismo e ao comunismo no processo dos 23 ativistas do Rio de Janeiro é mais um exemplo, agora numa forma mais acabada, do temor que a impressa corporativa, os órgãos de repressão e as autoridades legais e judiciárias nutrem contra essa ideologia. Um episódio no início de 2013 é igualmente exemplar: diante do violento despejo da Aldeia Maracanã promovido pela PM-RJ, representantes dos direitos humanos condenaram a ação policial e, em resposta às críticas que recebeu, o comando da PM-RJ, via sua assessoria de imprensa, lançou uma nota pública se justificando, dentre outros motivos, pela presença de uma bandeira anarquista no prédio ocupado pelos indígenas:

\begin{abstract}
A Polícia Militar reitera que a ação levada a efeito para garantir o cumprimento da decisão judicial, a integridade física dos manifestantes e a garantia da lei e da ordem foi fundamental para que não houvesse uma tragédia de proporções incalculáveis. O símbolo do Anarquismo que tremulava nas janelas do antigo museu do índio revela o verdadeiro objetivo de muitos que hoje se voltam contra a atuação da Polícia Militar. (PM-RJ, Nota Oficial, 23/03/2013. Os grifos são meus).
\end{abstract}

A criminalização e o temor da ideologia e prática anarquista não são novos na história do Brasil. Em 1900 o jurista e político Rui Barbosa publicou no jornal $A$ Imprensa um artigo intitulado "O perigo anarquista", com objetivo de alertar para as ameaças das "forças hediondas da anarquia", fazendo referência às teses do racistacientífico Cesare Lombroso que caraterizava "o anarquista" numa categoria criminológica. Rui Barbosa escreveu num contexto onde predominavam leis para restringir a entrada de imigrante ou expulsá-los se suas ações fossem consideradas ameaças à lei e à ordem, a exemplo da Lei 1641 de 7 de janeiro de 1907, batizada de "Lei Adolfo Gordo"5.

Além da atualização do medo irracional e da criminalização ao ideário anarquista, promovidos pela mídia corporativa pelo aparelho repressivo legal do Estado, 
as mobilizações e o levante popular de junho de 2013 também estimularam debates nos meios acadêmicos e de militância política sobre o anarquismo e, especialmente, sobre Bakunin. Nos últimos anos proliferaram-se os cursos, seminários, fóruns e conferências dedicados ao pensamento anarquista e os fundamentos do bakuninismo.

As publicações também ganharam novas contribuições com a edição da obra $D e$ baixo para cima e da periferia para o centro: textos políticos, filosóficos e de teoria sociológica de Mikhail Bakunin, organizada por Andrey Cordeiro Ferreira e Tadeu de Souza Toniatti (2014), que possui obras inéditas de Bakunin em português, destaque para os três documentos secretos, O império Knuto-germâmico e Considerações filosóficas sobre o fantasma divino, o mundo real e o homem, e das Obras escolhidas de Mikhail Bakunin (2015), que reúne numa única publicação textos já publicados em português, com destaque para a obra Federalismo, socialismo e antiteologismo.

O crescimento do interesse sobre o tema também motivou os adversários do anarquismo no campo do socialismo para o debate. Assim, o setor de formação política do Partido Socialista dos Trabalhadores Unificado (PSTU), de orientação trotskista, se dedicou em alimentar polêmicas, em divulgar suas críticas e sua concepção do que é anarquismo:

O termo anarquia provém do grego (an + arkhos) e quer dizer "ausência de governo" ou "ausência de poder". Ou seja, anarquia não quer dizer "ausência de ordem" ou "desordem", como em geral se pensa. Ao contrário, os anarquistas visam estabelecer a mais completa e perfeita ordem social. Porém, acreditam que esta ordem só pode ser estabelecida se todo governo e todo poder forem abolidos (CANARY, 2013).

Essa definição reproduz, em grande medida, a definição dada por Preobrazhenski, segundo o qual, o 'término 'anarquía', de origen griego, significa ausencia de todo poder. Por tanto, los anarquistas son personas que aspiran a un régimen social en el que no ha de existir ningún tipo de poder o imposición, donde ha de reinar la libertad absoluta" (PREOBRAZHENSKI, 2005, p. 17).

A tentativa de entender o significado político da ideologia e teoria anarquistas a partir da origem etimológica da palavra não é exclusividade do campo comunista, pois esse também é o caminho comum nos campos liberal e libertário. Como exemplo da abordagem liberal pode-se citar o verbete do Dicionário de política, organizado por Norberto Bobbio:

O termo Anarquismo, ao qual frequentemente é associado o de "anarquia", tem uma origem precisa do grego anarcia, sem Governo: através deste vocábulo se indicou sempre uma sociedade, livre de todo o domínio político autoritário, na qual o homem se afirmaria apenas através da própria ação 
exercida livremente num contexto sociopolítico em que todos deverão ser livres (BRAVO, 1998, p. 23).

As abordagens dos campos comunista e liberal ${ }^{6}$, guardadas as devidas nuances, partem de premissas abstratas e reducionistas. Estabelecem uma definição apriorística e a-histórica, a partir da qual tentam enquadrar um conjunto de teorias, organizações, práticas políticas e filosofias individuais, por vezes distintas e até contraditórias, ignorando os contextos históricos e a própria inserção concreta nas lutas sociais daqueles que são enquadrados nessa definição abstrata de anarquismo.

Apesar dos eventuais debates em espaços acadêmicos ou de militância política, da citação em autos policiais ou das brincadeiras e anedotas nas redes sociais, o fato é que Bakunin e, especialmente, sua ideologia e teoria são praticamente desconhecidos. Mesmo nos espaços acadêmicos e de militância política, pouco se conhece e se debate sobre ele e ainda predominam as interpretações superficiais e dogmáticas. Portanto, o objetivo do presente artigo é contribuir para o melhor entendimento da ideologia e da teoria desenvolvida pelo anarquista russo durante sua militância na Europa do século XIX.

O presente trabalho parte da noção de anarquia social como uma chave de entrada para a compreensão do pensamento revolucionário de Bakunin, pois é, utiliza exatamente aquela noção menos compreendida do seu sistema teórico-ideológico e, numa perspectiva imanente, procura demolir seus críticos a partir de seus próprios fundamentos.

\section{Anarquia do capital versus anarquia social: o contexto europeu do século XIX}

Oriundo de uma família aristocrática vinculada aos estamentos militares da russa czarista, Bakunin, como afirma o pesquisador Andrey Ferreira, tem sua trajetória militante e o desenvolvimento de sua teoria revolucionária profundamente influenciadas pela tradição insurgente conspirativa dos revolucionários russos, cujo marco foi a revolta dos dezembristas de 1825 (FERREIRA, 2010, p. 7). Não por acaso sua trajetória militante é forjada nas lutas insurrecionais do final da década de 1840, quando, durante o levante proletário conhecido como a Primavera dos Povos de 1848, participou da

6 Para um aprofundamento do debate sobre a conceituação e a historiografia do anarquismo ver Ferreira (2014).

Em Debat: Rev. Dig., ISSNe 1980-3532, Florianópolis, n. 11, p. 26-46, jan-jun, 2014. 
rebelião popular em Praga e, no ano seguinte, participou de outra insurreição popular, desta vez na cidade alemã de Dresden.

Por causa de sua militância revolucionária foi perseguido, acusado de terrorismo e condenado à morte. A pena capital é convertida em trabalhos forçados perpétuos. Em 1851 é extraditado para a Rússia, onde inicialmente é prisioneiro em São Petersburgo e depois exilado na Sibéria. Em 1861 ele fugiu da Sibéria para o Japão, passou pelos EUA e retornou para a Europa.

No que diz respeito à sua trajetória intelectual, começou seus estudos por volta de 1836, depois de abandonar o serviço militar, se insere nos círculos acadêmicos de Moscou, onde debate as teorias filosóficas de Kant, Fichte, Feuerbach e Hegel. Em 1840 se muda para a Alemanha para aprofundar seus estudos e tem contato com as teorias dos socialistas franceses, principalmente Proudhon, que conheceu pessoalmente em Paris.

Voltando para as atividades políticas no início da década de 1860, retoma seus antigos contados, reencontra Marx em Londres e Proudhon em Paris, depois se instala na Itália, de onde articula a organização de uma sociedade secreta revolucionária, denominada Fraternidade Internacional, cujo programa é desenvolvido em três documentos secretos, escritos em 1864 (FERREIRA E TONIATTI, 2014).

Bakunin se insere nos debates e nos processos organizativos em curso: a Liga da Paz e da Liberdade, que reunia setores do republicanismo radical e tinha uma composição policlassista, e a Associação Internacional dos Trabalhadores (AIT), que reunia setores do movimento dos trabalhadores de diversos países da Europa. No período entre 1867-68, rompe com a Liga da Paz, em seu congresso realizado em Berna, ao apresentar como tese sua obra Federalismo, socialismo e antiteologismo (1868). Dessa ruptura é organizada a Aliança Internacional da Democracia Socialista que adere à AIT.

A militância de Bakunin e o próprio desenvolvimento do anarquismo, enquanto teoria e ideologia revolucionárias da classe trabalhadora, estão inseridos, portanto, num ciclo revolucionário europeu que tem como marco inicial a Primavera dos Povos de 1848, que deve ser entendida como uma onda insurrecional de dimensões globais, tal como descrita pelo historiador Eric Hobsbawm, destacando a França com o centro importante da onda revolucionária, que se estendeu para a Alemanha, Áustria, Hungria e Itália, sem esquecer que o historiador marxista cita as insurreições que também ocorreram no Brasil e na Colômbia (HOBSBAWN, 1982, p. 26). 
Durante a década de 1850 esse ciclo revolucionário entrou numa fase caracterizada pela reação, isto é, segundo historiadores como Jonathan Sperber e G. D. H. Cole, o período entre 1850-59 pode ser considerado a era da reação, pois os governos da Europa promoveram uma onda repressiva sobre os movimentos de contestação como uma resposta às revoluções de 1848-49 (Sperber, 2009: 81), por isso, a década de 1850 é considerada "quase morta para o socialismo" Cole, 1974, p. 11). Os governos da França, Prússia e Áustria se converteram em verdadeiros Estados policiais, aumentando significativamente seus efetivos de repressivos. As forças policias de Paris e Berlim foram quadruplicadas (SPERBER, 2009, p 82). Assim, os países que ainda tinham alguma liberdade de expressão, como Inglaterra, Estados Unidos e Suíça, receberam exilados da França, Itália, Alemanha e Áustria-Hungria.

A era da reação foi também um contexto de conflitos e guerras entre nações. $\mathrm{O}$ principal conflito foi a Guerra da Crimeia (1853-1856), que opôs o Império Russo à coalização Anglo-Franco-Sarda Outros conflitos que se desdobraram foram a Segunda Guerra da Independência da Itália (1859), Guerra Austro-Prussiana (1866), Guerra Austro-Italiana (1866) e o domínio russo sobre a Polônia.

Em contrapartida, a economia capitalista estava em franca ascensão. A industrialização, puxada pela Inglaterra, se expandiu pela Europa e nos EUA, como afirma Michel Beud

no decorrer do século XIX, é principalmente através da instalação da indústria mecanizada que se opera a extensão do modo de produção capitalista. Multiplicam-se as "fábricas" que vimos nascer na Inglaterra no fim do século XVIII; na própria Inglaterra, mas também na Bélgica, na França, na Suíça, na Alemanha, nos Estados Unidos (BEAUD, 1987: 138).

O desenvolvimento industrial passou por duas fases: um período de expansão (1800-1830) e um período de crescimento contínuo a partir de 1830, crescimento que se intensifica na década de 1860 com o apoio das políticas estatais (BEAUD, 1987, p. 159). Dentre as principais ações estatais para impulsionar a industrialização estavam as ofensivas imperialistas e neocoloniais (BEAUD, 1987, p. 61 e 165).

Essa expansão capitalista é imperialista e monopolista, como o próprio Bakunin teorizou, dando continuidade aos estudos de Proudhon sobre o monopólio capitalista. Entre 1850 e 1870 um processo se consolidou: a tendência de desaparecimento das pequenas empresas e a concentração de capital nas grandes empresas. Esse foi o processo de concentração e de expansão em escala internacional do capitalismo monopolista, garantido pela "brutalidade organizada dos Estados", que viabilizaram, como afirmou 
Bakunin, "a grande exploração financeira, comercial e industrial, a grande espoliação internacional; alguns milhares de homens internacionalmente solidários entre si e dominando, através do poder dos seus capitais, o mundo inteiro" (BAKUNIN, 1979, p. 12-13).

Assim, esse ciclo revolucionário é também um ciclo de expansão do capitalismo, da passagem da fase de acumulação concorrencial (1760-1870) para acumulação monopolista (1871-1930), nas palavras de Proudhon, da passagem da guerra civil, a concorrência, para o massacre dos prisioneiros, o monopólio (PROUDHON, 2007, p. 248). Esse período de expansão e de mudança no regime de acumulação capitalista é caracteriza como anarquia econômica, ou anarquia do capital. Trata-se do domínio do capitalismo, do sistema das contradições econômicas, o qual, segundo Proudhon, impõe uma taxa crescente de desigualdade social e econômica, resultante da exploração do trabalho, que garante a riqueza das classes dominantes e a pobreza e a miséria do proletariado, "visto que uma nação, como a humanidade inteira, é uma grande sociedade industrial que não pode agir fora de si mesma, fica demonstrado que nenhum homem pode enriquecer-se sem que outro empobreça" (PROUDHON, 1975, p. 189).

Num processo dialético, o ciclo revolucionário entra na década de 1860 em uma nova fase, superando o refluxo da década anterior e assumindo o formato de lutas organizadas pela classe trabalhadora tendo como princípio o internacionalismo e a estrutura orgânica da AIT, fundada em 1864, por trade-unionistas ingleses e por mutualistas franceses. Assim, a AIT deve ser entendida como parte do ciclo revolucionário europeu, que entra na fase do internacionalismo operário, não mais como bandeira de ordem, mas como uma organização efetiva e atuante. Bakunin resume bem o papel cumprido pela AIT nesse contexto revolucionário:

\footnotetext{
A Internacional, colocando, assim, o proletariado fora do estado político e do mundo burguês, é um novo mundo, o mundo da solidariedade do proletariado de todos os países. Este é o mundo do futuro; é de um lado o herdeiro legítimo, mas também a demolição e o enterro de todas as civilizações históricas, de todos os privilegiados, e como tal completamente exauridas e condenadas à morte; consequentemente forçou a criação de uma nova civilização baseada na ruína de todas as autoridades divinas e humanas, de toda escravidão e todas as desigualdades. Esta é a missão, e, portanto, este é o verdadeiro programa da Internacional, não oficial - todos os deuses pagãos e paraíso cristão nós mantemos! - Mas implícita, inerente à sua organização. Seu programa oficial, vou repeti-lo mil vezes, é simples e, aparentemente, muito modesto: é a organização para além da solidariedade internacional para a luta econômica do trabalho contra o capital. A partir desta base o material surge em seguida o novo modelo social, intelectual e moral. (BAKUNIN, 1910, p. 437).
} 
A AIT assumiu, na perspectiva de Bakunin, uma dupla função: intensificaria as contradições entre a classe trabalhadora e a burguesia e, simultaneamente, fortaleceriam os laços de solidariedade entre os trabalhadores. Consequentemente, essa dupla função das greves, produziriam uma dupla ação: a negação da ordem burguesa e afirmação de uma nova ordem social.

Não era apenas Bakunin e os demais militantes da AIT que entendiam ou enxergavam nessa organização internacional de trabalhadores uma ameaça à ordem vigente. Os governos e a própria burguesia a identificava como uma ameaça. No seu texto, A dupla greve de Genève, publicado no Jornal L'Egalité, em maio de 1869, por exemplo, o anarquista russo se refere aos ataques desferidos contra a AIT pelo Jornal de Genève: "Os burgueses nos provocam. (...) Eles nos caluniam e nos insultam em seus jornais; deturpam falseiam e inventam fatos" (BAKUNIN, 1979, p. 5).

Os ataques à AIT não se limitavam a criminalização via órgãos da imprensa burguesa, na verdade, conforme aumenta a organização da associação e, especialmente, sua participação nas greves e lutas dos trabalhadores, aumentava a repressão sobre suas seções. Foi o que ocorreu com a seção parisiense ${ }^{7}$, quando em dezembro de 1867 o Imperador Napoleão III, em represália à intensa atividade política nas greves e movimentos operários, moveu processos criminais contra os dirigentes da AIT. A sede de Paris foi invadida pela polícia, que também fez buscas nas casas de alguns dirigentes. Todos os quinze membros da Comissão da seção foram processados criminalmente, sobre pressão abandonaram os cargos e uma nova Comissão foi eleita. Os quinze processados foram condenados ao pagamento de multas e o bureau de Paris foi abolido. Os membros da segunda comissão também foram processados e condenados ao pagamento de multas e três meses de prisão e a seção da AIT novamente fechada. A alternativa foi a filiação individual à seção londrina.

Foi nesse contexto, numa fase de reorganização das forças coletivas do proletariado internacional, num período de expansão do capitalismo urbano-industrial e de reposicionamento, conflagração e expansão das potências imperialistas, que o anarquismo se desenvolve e assumiu os contornos e o conteúdo de uma teoria e ideologia revolucionárias da classe trabalhadora.

O anarquismo, enquanto teoria e organização revolucionária se define no interior do movimento de massas formado pela AIT, que seria, naquele contexto, também denominado de bakuninismo. É nesse sentido que a categoria anarquismo é inserida num novo regime de discursividade e

7 Conferir o relato do anarquista suíço e membro da AIT James Guillaume (2009, p. 150-151).

Em Debat: Rev. Dig., ISSNe 1980-3532, Florianópolis, n. 11, p. 26-46, jan-jun, 2014. 
historicidade, geradoras de uma experiência histórica particular. Essa primeira resemantização funde o aspecto negativo da categoria anarquista (que designava os que queriam revolucionar sempre) com um aspecto positivo (uma teoria e uma práxis determinada). E foram estes intelectuais, militantes e organizações os construtores dessa categoria anarquismo. (FERREIRA, 2014, p. 32).

Andrey Ferreira defende a tese do anarquismo como um fenômeno da Primeira Internacional argumentando que a partir de sua militância para organizar um movimento revolucionário, Bakunin estabelece uma rede de militantes visando à construção de uma organização anarquista revolucionária, a "Fraternidade", e ao se inserir na AIT consolida sua aliança política com os militantes proudhonianos do movimento operário. Portanto, seria dessa articulação orgânica que o anarquismo assume seu papel histórico nas lutas de massa e nos movimentos insurgentes da classe trabalhadora, ao passo que permitiu a continuidade da obra de Proudhon, iniciada ainda nos anos de 1840, num lugar de destaque da retomada da organização e do internacionalismo proletário.

Esta continuidade entre o anarquismo de Proudhon e o de Bakunin seria estabelecida dentro do movimento socialista do século XIX, especialmente na Associação Internacional dos Trabalhadores (ATI), com a adesão de diversos membros proudhonistas da AIT à organização política formada sob a inspiração de Bakunin. Mas é também no plano do pensamento político que se manifesta uma profunda continuidade. Bakunin fazia questão de afirmar isso nos seus escritos. Seriam os proudhonianos revolucionários, reunidos em torno de Bakunin que formariam parte de um campo que abrangia uma teoria, uma organização revolucionária e um sindicalismo revolucionário que se expressava na categoria "anarquia". (FERREIRA, 2014, p. 31-32).

A tese do pesquisador brasileiro se aproxima daquelas teses defendidas por Lucien Van der Walt, nas suas obras conjuntas com Michael Schmidt (2009) e com Steven J. Hirsch (2010), embora Ferreira não faça referência às referidas obras. Van der Walt, Schmidt e Hirsch argumentam que

o termo "anarquismo" é muitas vezes aplicado de forma muito vaga, este
volume usa uma definição restrita. O movimento anarquista moderno surgiu a
partir da década de 1860 , no contexto de um movimento operário expandindo
internacionalmente, ligados entre si na Associação Internacional dos
Trabalhadores (ou Primeira Internacional, 1864-1877). Os debates sobre a
questão do estado entre Karl Marx e Bakunin (1814-1876) foram
fundamentais no estabelecimento do atual anarquistmo como uma forma
distinta do socialismo. (VAN DER WALT e HIRSH, 2010, p. xxxvi).

Mais do que isso, os três autores defendem a tese da impossibilidade de dissociação entre o anarquismo, tal como eles o entendem enquanto fenômeno histórico global das lutas operárias e das lutas insurgentes, do movimento dos trabalhadores que eles definem como sindicalismo, em inglês syndicalism.

O sindicalismo [syndicalism] constitui, em grande medida, parte da história do anarquismo. Muitas abordagens apresentaram esse sindicalismo como algo distinto do anarquismo ou mesmo hostil a ele. (...) Contrariamente, 
demonstramos que o sindicalismo sempre foi parte da ampla tradição anarquista. Frequentemente se assume que esse sindicalismo [syndicalism] surgiu pela primeira vez na França dos anos 1890; demonstramos, no entanto, que foi Bakunin, nos anos 1860, e não Sorel, 40 anos depois, seu principal teórico e que toda uma primeira onda desse sindicalismo [syndicalism] foi levada a cabo entre os anos 1870 e 1880. (VAN DER WALT e SCHIMIDT, 2009, p. 16).

Aqui é fundamental esclarecer que para os autores o conceito de sindicalismo [syndicalism] para designar o modelo e concepção de movimento sindical revolucionário desenvolvido conjuntamente com o bakuninismo no interior da AIT, por isso o sindicalismo [syndicalism] se confunde com o anarquismo, sendo uma das suas variantes e distinguindo-se, consequentemente, do trade-unionismo, que constitui o movimento sindical corporativista e reformista. Assim, os autores definem o sindicalismo [syndicalism] como "uma variação do anarquismo e esse movimento sindicalista é parte da ampla tradição anarquista" (VAN DER WALT E SCHIMIDT, 2009, p. 16).

As teses de Ferreira, Van der Walt, Schmidt e Hirsch rompem praticamente com todas as correntes da historiografia sobre o anarquismo, e também sobre o sindicalismo, predominantes no século XX. O esforço para contextualizar e identificar os sujeitos concretos inseridos na luta de classes, e utilizando uma abordagem imanente, isto é, mergulhando nas próprias concepções, ideologias e teorias desenvolvidas pelos sujeitos históricos analisados, os levou a conclusões que modificam significativamente toda a compreensão que até o momento se tinha sobre o tema.

Considerando o contexto da década de 1860, o anarquismo se desenvolveu em oposição à ofensiva da anarquia econômica do capital, isto é, no contexto da expansão do capitalismo monopolista e imperialista, em meio à conflagração entre as potências imperialistas e, fundamentalmente, no processo de reorganização das forças coletivas do proletariado, na qualidade de alternativa revolucionária para a emancipação proletária. Assim, a anarquia social, que brota dos subterrâneos da sociedade, de baixo para cima, das lutas sociais, que assumiam cada vez mais o formato das greves operárias, que se mesclavam com as revoltas insurgentes e apontavam para a greve geral insurrecional, ou seja, a única força capaz de superar a anarquia econômica.

As notícias relativas ao movimento operário europeu podem resumir-se numa palavra: greves. Na Bélgica, greve dos tipógrafos em várias cidades, greve dos fiandeiros em Gande, greve dos tapeceiros em Bruges; na Inglaterra, greve iminente dos distritos manufatureiros; na Prússia, greve dos mineiros de zinco; em Paris, greve dos pedreiros e pintores; na Suíça, greves em Basileia e em Genebra. À medida que avançamos as greves multiplicam-se. Que quer dizer isto? Que a luta entre o trabalho e o capital se aguça cada vez 
mais, que a anarquia econômica é cada vez mais profunda, e que caminhamos a passos largos para o fim inevitável a que nos conduz esta anarquia: a revolução social. (BAKUNIN, 1979, p. 10-11).

Considerando a dialética antinômica bakuninista, para a destruição da anarquia econômica do capital, desenvolve-se, enquanto força coletiva do proletariado, a anarquia social, isto é, a destruição simultânea da propriedade privada e do poder de Estado, para a construção de uma nova ordem social, da coletivização do trabalho e do poder político estruturado na federação livre das comunas, ou seja, na igualdade econômica e na liberdade política. Mas o primeiro passo para a construção da anarquia social é a insurgência do trabalho.

\section{O trabalho insurgente e a revolução social}

A anarquia social, nas perspectivas revolucionárias de Proudhon e Bakunin, resulta da luta insurgente da classe trabalhadora, de sua luta emancipatória, da sua capacidade de organização, desenvolvimento de sua força coletiva, de sua capacidade destrutiva e construtiva, numa só palavra, da revolução social. Mas para o entendimento desses conceitos que constituem a teoria revolucionária anarquista se faz necessária a compreensão das suas concepções ontológicas, do materialismo e da dialética desenvolvidos pelos dois anarquistas.

Como já foi afirmado, o anarquista russo é um continuador da obra de Proudhon, essa continuidade é explícita na dialética serial antinômica e no materialismo sociológico de Bakunin. A dialética serial proudhoniana é antinômica, negativa e antitética, isto é, ao contrário da dialética tricotômica de Hegel e do materialismo histórico, se opõe a noção de síntese e pressupõe a multiplicidade de fatores para o entendimento dos fenômenos socais e históricos (GURVITCH, 1987, p 100). Assim, a apropriação da dialética serial por Bakunin se explicita na sua antologia do trabalho:

O cumprimento desta tarefa imensa, e que a natureza particular do homem lhe impõe como uma necessidade inerente ao seu ser - o homem é forçado a conquistar sua liberdade - o cumprimento desta tarefa não é somente uma obra intelectual e moral; é, antes de tudo, tanto na ordem do tempo quanto do ponto de vista de nosso desenvolvimento racional, uma obra de emancipação material. $\mathrm{O}$ homem só se torna realmente homem, só conquista a possibilidade de sua emancipação interior na medida em que consegue romper as pesadas correntes de escravo que a natureza exterior coloca sobre todos os seres vivos. (...) Daí também resulta, para o animal, a necessidade de lutar durante toda a sua vida contra os perigos que o ameaçam de fora; de sustentar sua existência própria, enquanto indivíduo, e sua existência social, enquanto espécie, em detrimento de tudo o que o rodeia: coisas, seres orgânicos e vivos. Daí, para os animais de qualquer espécie, a necessidade do trabalho. (BAKUNIN, 2014, p. 374-375). 
O trabalho, enquanto fazer coletivo, é ação emancipatória e, consequentemente, fundante da sociedade, que, por sua vez, é a condição material da existência da humanidade. Assim, o trabalho tem uma dupla dimensão: emancipatória, pois liberta a humanidade do julgo da natureza externa, e criativa/transformadora, pois cria o mundo social transformando a natureza. Portanto, foi aplicando a dialética proudhoniana que Bakunin desenvolveu sua teoria sobre o trabalho coletivo enquanto ação emancipatória, criadora e transformadora. Além de criar a sociedade e transformar a natureza, o trabalho coletivo também permite que a humanidade transforme a si mesma. Trata-se da dialética ação-reação, onde a ação criadora e transformadora do trabalho coletivo se volta sobre a própria humanidade, transformando-a. Assim, a humanidade transforma a si mesma e a sociedade da qual ela é o produto imediato.

\begin{abstract}
Esta é, pois, a maneira como o homem transformou e continua a transformar, a vencer e dominar seu meio, a natureza exterior. (...) Mas o homem não se contenta desta ação sobre a natureza propriamente exterior. Enquanto inteligência, capaz de fazer abstração de seu próprio corpo e de toda a sua pessoa, e de considerá-la como um objeto exterior, o homem, sempre levado por uma necessidade inerente ao seu ser, aplica o mesmo processo, o mesmo método, para modificar, para corrigir, para aperfeiçoar sua própria natureza. Há uma dominação interior da qual o homem deve, igualmente, se libertar. Esta dominação apresenta-se a ele, primeiro, sob a forma de suas imperfeições e fraquezas, ou até mesmo de suas doenças individuais, tanto corporais quanto intelectuais e morais; depois, sob a forma mais geral da sua brutalidade ou de sua animalidade, do ponto de vista de sua humanidade, esta última realizando-se progressivamente nele, através do desenvolvimento coletivo de seu meio social. (BAKUNIN, 2014, p. 380).
\end{abstract}

Se a força coletiva dos trabalhadores é emancipadora, os sistemas de trabalho, escravidão, servidão e assalariamento, são a negação da dimensão criativa e emancipatória do trabalho. As relações sociais assimétricas, construídas historicamente pelos sistemas sociais desiguais, impuseram relações de trabalho determinadas por estruturas de exploração e dominações de classe. Considerando a dialética serial antinômica, é pela ação coletiva, ou melhor, é pelo trabalho coletivo que os homens constroem as sociedades, entretanto, contraditoriamente, é pela ação violenta e política das classes dominantes que o trabalho coletivo é convertido em fonte de exploração e opressão sobre as classes trabalhadoras.

Os fundamentos da análise anarquista das relações de trabalho no capitalismo encontram-se na obra clássica $O$ que é a propriedade?, publicada em 1840, onde Proudhon identificou a propriedade privada como a negação do trabalho coletivo e como a fonte de exploração do trabalho, concluindo que a propriedade é um roubo (PROUDHON, 1975, p. 82). O anarquista francês lançou as bases teóricas da crítica 
anarquista ao capitalismo, e se tornou o precursor da crítica radical da propriedade privada, ao mesmo tempo em que desenvolveu as teorias do valor trabalho e da maisvalia numa abordagem revolucionária (GURVITCH, 1980).

O trabalho coletivo é responsável pela transformação da natureza em coisas socialmente úteis, ou seja, é responsável pela produção do valor. Somente as forças coletivas dos trabalhadores, na sua dimensão socioeconômica, têm a propriedade de produz valor:

Os capitais, os utensílios e as máquinas são paralelamente improdutivos. O martelo e a bigorna sem ferreiro nem ferro não forjam; o moinho não mói sem moleiro nem grão, etc. Amontoem utensílios e matérias-primas; deitem uma charrua e sementes num solo fértil; montem uma forja, acendam o fogo, nada produzirão. (PROUDHON, 1975, p. 142-143).

Entretanto, os frutos do trabalho coletivo são explorados pela classe burguesa. $\mathrm{O}$ trabalho coletivo não pode ser pago na forma de salários individuais, por isso, a extração da mais-valia, imposta pelo regime da propriedade privada, significa a exploração da força coletiva dos trabalhadores. Não se pode pagar com salários individuais aquilo que é coletivamente produzido, pois a força coletiva não é a soma dos esforços individuais. Por isso, a força coletiva no plano socioeconômico, representa uma contradição direta com a existência da propriedade privada. A justiça somente será alcançada quando os trabalhadores se apoderarem da totalidade do trabalho coletivo, ou seja, com a abolição da propriedade privada.

Bakunin resume a teoria proudhoniana da exploração da mais-valia em 1864:

Esta potência do trabalho associado contém todo o mistério da prepotência do capital e da propriedade. Suponhamos que, possuidor de um capital qualquer, eu queira empregá-lo ou numa indústria qualquer, ou na cultura da terra. Eu compro todas as matérias-primas e todos os instrumentos de trabalho, ou então alugo a terra que eu quero cultivar e pela qual eu pago a renda ao proprietário. Eu alugo, além disso, 50 operários. Suponhamos que eu seja bom senhor, e que lhes pague um salário não conforme à fome que os força a oferecer-me seu trabalho, mas justo, ou seja, propriamente o equivalente do trabalho individual de cada um. Como tínhamos reconhecido que somente o trabalho produz riqueza, se eu pagar aos operários o justo valor de seu trabalho, o que sobrará para mim? Aparentemente, nada, e se eu conduzir meus negócios com sabedoria, no fim do ano, despesas e receitas balanceadas, comparadas, chegarei a zero. Não terei dívidas, nem um centavo de renda. Mas, na realidade, terei muito: terei todo o excedente produzido pela potência coletiva e organizada do trabalho associado, do qual me apoderei injustamente, que eu simplesmente roubei. Explico-me: segundo esta maravilhosa lei da divisão do trabalho, descoberta e tão bem analisada por Adam Smith, 50 operários, se trabalharem cada um separadamente, fazendo cada um a obra completa, produziam infinitamente menos que se trabalhassem, como aconteceria hoje no mundo civilizado inteiro, ao mesmo tempo, e juntos, em associação bem organizada, cada um fazendo apenas uma parte da obra inteira - ou seja, que a totalidade dos produtos do trabalho coletivo e organizado de 50 operários, comparado à soma destes mesmos 
operários, apresenta um imenso excedente de riqueza, excedente que é o produto direto da coletividade. Pois bem, o capitalista e o empreendedor se apropriam deste excedente, que faz sua renda líquida. Mas de que direito se apropria? A força coletiva dos operários lhe pertence? Ela lhe pertenceria, se eles fossem seus escravos. Mas então, ele não lhes daria nem mesmo o salário, para pagar seu trabalho individual separado, e bastaria vesti-los e alimentá-los para fazê-los viver, apenas, e para dar-lhes a força de trabalhar. Mas supõe-se que eles sejam livres, e, portanto, a potência coletiva de seu trabalho pertence tão pouco ao capitalista quanto o trabalho individual de cada um. Tomando-a para si, ele a roubou. E, mais uma vez, Proudhon teve razão ao dizer "que a propriedade é um roubo". (BAKUNIN, 2014, p. 99).

A exploração do trabalho é um dos aspectos destrutivos das forças coletivas: a submissão das massas trabalhadoras à exploração. $O$ trabalho coletivo, que é a emancipação da humanidade, foi, dialeticamente, reduzido à condição de miséria pelas forças destrutivas dos diversos sistemas de exploração da força de trabalho. A exploração da mais-valia é a negação do trabalho emancipatório.

As séries dialéticas criação-destruição e revolução-contrarrevolução assumem, no capitalismo, a realidade histórica do antagonismo entre capital e trabalho, a dialética entre proletariado e burguesia. O proletariado, por ser a classe que trabalha, é depositário de uma força coletiva criadora, responsável pela transformação da natureza, da sociedade e da sua própria condição. A própria sociedade humana é um fenômeno da natureza, mas o fenômeno humano se distingue pela ação criativa do trabalho.

Todas as coisas são apenas aquilo que fazem: seu fazer, sua manifestação exterior, sua ação incessante e múltipla sobre todas as coisas que estão fora dela, é a exposição completa de sua natureza, de sua substância, ou daquilo que os metafísicos, e o sr. Littré com eles, chamam de seu ser íntimo. Ela não pode ter nada em seu suposto interior que não seja manifesto em seu exterior: numa palavra, a sua ação e o seu ser são um. Poderão ficar surpresos com o que digo sobre a ação de todas as coisas, até as aparentemente mais inertes, de tanto que estamos habituados a só ligar o sentido desta palavra a atos que sejam acompanhados de uma certa agitação visível, de movimentos aparentes, e, principalmente, da consciência, animal ou humana, daquele que age. (...) Na natureza, tudo é movimento e ação: ser não significa nada além de fazer. Tudo o que chamamos de propriedades das coisas: propriedades mecânicas, físicas, químicas, orgânicas, animais, humanas, não são nada além de diferentes modos de ação. Toda coisa é uma coisa determinada ou real apenas pelas propriedades que ela possui; e ela as possui apenas enquanto as manifesta, já que as propriedades determinam as suas relações com o mundo exterior; disto resulta que toda coisa só é real enquanto se manifesta, enquanto age. A soma das suas ações diferentes, eis aí todo o seu ser (BAKUNIN, 2014, p. 429-430).

Pode-se concluir, portanto, que o materialismo de Bakunin é um materialismo sociológico, onde a agência ocupa um lugar central para o entendimento dos fenômenos sociais e históricos, pois a ontologia do ser se realiza no seu fazer, ou seja, na sua ação coletiva, social e histórica, principalmente na forma de trabalho coletivo. "Assim, o que chamamos de mundo humano não possui outro criador imediato além do próprio 
homem que o produz" (BAKUNIN, 1988, p. 68). Aqui se encontra a dialética entre a existência material da sociedade e o fazer coletivo, pois é condição determinante da humanidade a vida em sociedade e essa vida em sociedade, entendida na sua totalidade, é produzida e reproduzida pelo fazer coletivo. "Aqui temos outra enunciação central: o ser não é senão o fazer, a natureza e a sociedade não são senão a continua dinâmica de ação-reação e progresso-estagnação. O modo de ser não é senão um modo de fazer" (FERREIRA, 2013, p. 14). Por isso, o pressuposto de toda análise é a experiência concreta, sendo que a ação, a consciência e as ideias são, simultaneamente, produto e produtoras de novas experiências.

Andrey Ferreira (2013) defende que, na perspectiva do materialismo sociológico e a dialética serial antinômica bakuninistas, a dialética autoridade/liberdade tem um lugar fundamental, pois esses dois princípios opostos, e complementares, historicamente se materializam em instituições, relações sociais, econômicas e políticas, nos processos históricos, nas revoltas e revoluções. Os grupos e classes sociais também assumem posições históricas que lhes colocam em oposição, ou seja, defendendo o princípio da autoridade ou da liberdade.

O conflito entre capital e trabalho também é resultante da série dialética autoridade/liberdade, pois o trabalho, enquanto atividade criativa é emancipatório.

\begin{abstract}
A mesma lei de solidariedade encontra-se no trabalho. Ela se chama associação e divisão do trabalho. A grande, a maior missão do homem, depois da liberdade, e condição fundamental desta, seu mais belo triunfo, sua felicidade e sua honra, ao mesmo tempo, seu único título de nobreza, é conquistar o mundo exterior, transformando-o, criando-o, por assim dizer, uma segunda vez, através do trabalho. Através do trabalho, o homem torna-se criador. (BAKUNIN, 2014, p. 89).
\end{abstract}

Ao contrário, o capital, ou melhor, o sistema da propriedade privada está centrado no princípio da autoridade que impõe a exploração sobre o trabalho coletivo. A exploração do trabalho coletivo constitui um sistema total, isto é, pressupõe as séries dialéticas economia-política e local-global, cujos desdobramentos históricos na sociedade capitalista adquiram as formas e conteúdos da dialética entre Estado e Capital. Segundo a teoria anarquista, o Estado, enquanto fenômeno sócio-histórico é uma das forças sociais que determinam as formas de organização da própria sociedade, por isso, o Estado não é entendido como um simples fenômeno derivado da estrutura econômica, mas como um fator determinante da estrutura social inclusive da economia. Ao mesmo tempo o Estado apresenta-se como forma histórica que marca o próprio desenvolvimento das sociedades humanas, desde a antiguidade até a modernidade. A 
emergência de Estados cada vez mais vastos e poderosos, e a tendência de sua expansão, é apontada por Bakunin como um dos principais fatores a influenciar história da humanidade, inclusive do desenvolvimento econômico. Assim, analisando todo processo histórico de formação dos Estados modernos, desenvolveu sua teoria do estatismo, que atribui ao Estado capitalista as seguintes características: a conquista e a dominação; a exploração do trabalho, o monopólio, o imperialismo e o sistema interestatal (BAKUNIN, 2003, p. 36).

Percebe-se que o estatismo tem uma dimensão econômica fundamental. E não se trata de uma dimensão secundária, indireta ou uma subordinação do Estado aos interesses econômicos das classes dominantes. Trata-se, na verdade, do entendimento do Estado como um fator econômico fundamental. Ou seja, existe uma dialética geral entre economia e política e uma dialética mais particular entre a tendência centralizadora dos poderes do Estado moderno, o autoritarismo, com a tendência de centralização monopolista de capitais na grande indústria, nos grandes bancos e grandes empresas comerciais. Há uma correspondência entre centralização de poderes e concentração de capitais (BAKUNIN, 2003, p. 35).

O entendimento da teoria do Estado e da noção de estatismo na abordagem anarquista é fundamental para a compreensão da sua crítica radical às instituições políticas estatais, crítica tão forte quanto a condenação da propriedade privada, pois, na verdade, considerando a dialética economia-política o Estado e a propriedade privada constituem um mesmo sistema de dominação política e econômica, historicamente materializam o princípio da autoridade como a negação da liberdade e da igualdade, a imposição da anarquia econômica.

Ao contrário das forças autoritárias e opressivas do Estado e do Capital, o trabalho, as forças coletivas do proletariado, que historicamente assumem as formas e os conteúdos das revoltas, das lutas, das organizações do campo e da cidade, são a materialização do princípio da liberdade. Assim, o trabalho insurgente é, dialeticamente, a negação do Estado e do Capital.

O futuro pertence hoje aos trabalhadores: os trabalhadores dos campos, aos trabalhadores das fábricas e das cidades. Todas as classes que estão acima, os eternos exploradores do trabalho das massas populares: a nobreza, o clero, a burguesia, e toda essa miríade de funcionários militares e civis que representam a iniquidade e o poder maléfico do Estado, são classes corruptas, atingidas pela impotência, doravante incapazes de compreender e querer o bem, poderosas somente para o mal. (BAKUNIN, 2008, p. 104). 
Recorrendo aos estatutos da AIT, que afirmam ser a emancipação dos trabalhadores obra dos próprios trabalhadores, Bakunin entende que o trabalho insurgente desenvolve um processo de autoconstrução da consciência da classe trabalhadora, ou seja, da consciência do pertencimento a uma coletividade, do desenvolvimento de uma força coletiva que luta para se libertar da exploração e da opressão capitalistas. Desse modo, na teoria bakuninista, na qualidade de força coletiva, a classe trabalhadora é sujeito histórico portador da sua própria consciência de classe. A consciência de classe não é um fenômeno exterior à própria classe, mas sim o resultado das suas condições materiais de existência, de suas experiências concretas enquanto classe, das suas lutas diárias contra a exploração e opressão impostas pelas classes dominantes, por isso, a classe trabalhadora é "socialista por todas as condições da sua existência material" (BAKUNIN, 1979, p. 59).

A organização e a luta dos trabalhadores são condições necessárias dos sujeitos históricos responsáveis pela constituição e pela história das sociedades humanas. A força coletiva em Bakunin não é outra coisa se não o livre exercício da vontade. Portanto, a ação classista significa a ruptura da condição de "objeto", de massa amorfa para a condição de sujeito. A vontade é a vontade coletiva, a vontade política, a vontade que existe na prática concreta, que se insurge contra a negação de sua liberdade, ou seja, da negação de seu próprio ser.

Considerando a tese bakuninista, a noção de ação espontânea passa a ter um sentido diferente, isto é, passa a ser entendida como ação classista, isto é, "a livre organização de seus próprios interesses, de baixo para cima, sem nenhuma ingerência, tutela ou coerção de cima” (Bakunin, 2003: 47). Em outras palavras, ação espontânea não é sinônimo de ação instintiva, desprovida de direção consciente, porque o "instinto" é visto como um reflexo mecânico muito elementar, portanto não se aplica à ação humana, pois essa possui uma reflexão sobre sua própria ação. A ação humana é, na verdade, o exercício da vontade, "sua vontade refletida, transforma-se nele e para ele em trabalho inteligente e livre" (BAKUNIN, 1988, p. 70).

Portanto, segundo a sociologia bakuninista, a ação espontânea das massas é a livre vontade da classe trabalhadora. A luta concreta é, necessariamente, uma luta consciente, detentora de intencionalidade, resultante do processo de autoconsciência. Sendo assim, não existem greves, movimentos, motins, qualquer expressão de revolta popular desprovidas de direção consciente. Sendo uma ação de classe, toda e qualquer revolta e forma de resistência são expressões concretas da consciência da classe Em Debat: Rev. Dig., ISSNe 1980-3532, Florianópolis, n. 11, p. 26-46, jan-jun, 2014. 
trabalhadora, ou seja, a ação da classe por si mesma que se insurge contra sua condição subalternizada.

A revolução social deve ser uma revolução proletária, internacional e antiestatista. A revolução social se distingue das revoluções políticas, como a Revolução Francesa e as demais revoluções burguesas, pois essas últimas significam somente mudanças nos regimes políticos, novas classes dominantes assumem a direção do Estado, mas mantêm intacto o sistema econômico, ou seja, as estruturas de exploração do trabalho. E, conclui Bakunin, "a liberdade política sem a igualdade econômica, ou em outras palavras, a liberdade no Estado, é uma farsa” (BAKUNIN, 2003, p. 72). Assim, a teoria bakuninista define a revolução social como a realização da "real igualdade social", ou seja, da "igualdade política, social e econômica, simultaneamente" (BAKUNIN, 1979, p. 62).

Para o desenlace revolucionário de fato é fundamental levar a organização dos trabalhadores às últimas consequências e radicalizar nas formas de luta, desenvolver a força coletiva dos trabalhadores a partir de experiências concretas de luta e de solidariedade classista. A solidariedade de classe deve romper as barreiras das categorias e as fronteiras nacionais. Por isso, Bakunin estabelece a estratégia da greve geral insurrecional, ou seja, a conversão das lutas de reivindicativas e de resistência em uma luta ofensiva contra o Estado e o Capital.

\section{Bibliografia}

BAKUNIN, Mikhail. De baixo para cima e da periferia para o centro: textos políticos, filosóficos e de teoria sociológica de Mikhail Bakunin. In: FERREIRA, Andrey

Cordeiro e TONIATTI, Tadeu de Souza (orgs). Niterói: Alternativa, 2014.

Estatismo e anarquia. São Paulo: Imaginário; Ícon, 2003.

. Federalismo, socialismo, antiteologismo. São Paulo: Cortez, 1988.

O princípio do Estado e outros escritos. São Paulo: Hedra, 2008.

O socialismo libertário. São Paulo: Global, 1979. 
. Oeuvres - Tomo IV. Paris, Stock Éditeur, 1910. (Biblioteque Sociologique, ${ }^{\circ}$

42).

BEAUD, Michel. História do Capitalismo de 1500 até nossos dias. São Paulo:

Brasiliense, 1987.

BRASIL. Ministério Público Estadual do Rio de Janeiro. Inquérito $n^{\circ} 0229018$ 262013.8.19.0001, volume 8, p. 1908. 2013.

BRAVO, Gian Marujo. Anarquismo. In BOBBIO, Norberto. Dicionário de política. Brasília: Editora da UnB,1998.

CANARY, Henrique. Marxismo e anarquismo, 2013. Disponível em: http://www.pstu.org.br/node/20138. Acesso em: mar 2014.

COLE, Georg Douglas H. Historia del pensamiento socialista II: marxismo y anarquismo - 1850-1890. Tercera reimpresión. México: Fondo de Cultura Económica, 1974.

FERREIRA, Andrey Cordeiro. Introdução: Anarquismo, pensamento e prática insurgentes: fenômeno da "Primeira internacional"? In: FERREIRA, Andrey Cordeiro e TONIATTI, Tadeu de Souza (orgs). De baixo para cima e da periferia para o centro: textos políticos, filosóficos e de teoria sociológica de Mikhail Bakunin. Niterói: Alternativa, 2014, p. 21-61.

Materialismo, anarquismo e revolução social: o bakuninismo como filosofia e como política do movimento operário e socialista. In: XXVII Simpósio Nacional de História. ANPUH, Natal, 2013.

Trabalho e ação: o debate entre Bakunin e Marx e sua contribuição para uma sociologia crítica contemporânea. Em Debate, Florianópolis (4): 1-23, 2010.

GUILLAUME, James. A Internacional: documentos e recordações, volume I. São Paulo: Imaginário, 2009.

GURVITCH, George. Dialética e sociologia. São Paulo: Vértice, 1987. Proudhon e Marx. Lisboa: Presença; São Paulo: Martins Fontes, 1980. 
HOBSBAWM, Eric. A era do capital: 1848-1875. $3^{\text {a }}$ ed. Rio de Janeiro: Paz e Terra, 1982.

LOPREATO, Chistina Roquette. O espírito das leis: anarquismo e repressão política no Brasil. In: Revista Verve (3): 75-91, 2003.

PREOBRAZHENSKI, Evgueni. Anarquismo y comunismo. Fundación Federico Engels: Madrid, 2005.

PROUDHON, Pierre-Joseph. O que é a propriedade? 2a ed. Lisboa: Estampa, 1975.

Sistema das contradições econômicas ou Filosofia da miséria. São Paulo: Escala, 2007. Tomo I.

SPERBER, Jonathan, Europe 1850-1914: Progress, Participation and Apprehension. New York, Pearson Longman, 2009.

VAN DER WALT, Lucien and SCHMIDT, Michael. Black Flame: The Revolutionary Class Politics of Anarchism and Syndicalism. Oakland; Edinburgh: AK Press, 2009.

end HIRSCH, Steven (ed.). Anarchism and Syndicalism in the Colonial and Postcolonial World, 1870-1940: the praxis of national liberation, internationalism, and social revolution. Leiden; Boston: Brill Academic Publishers, 2010.

WOODCOCK, George. História das ideias e movimentos anarquistas - v.1: a ideia. Porto Alegre: L\&PM, 2007. 